\title{
Einstein and the Cultural Roots of Modern Science
}

\section{Citation}

Holton, Gerald. Einstein and the cultural roots of modern science. In The Advancement of Science and Its Burdens, xiii-xlix. Cambridge, MA: Harvard University Press, 1998.

\section{Published Version}

http://www.hup.harvard.edu/catalog.php?isbn=9780674005303

\section{Permanent link}

http://nrs.harvard.edu/urn-3:HUL.InstRepos:40508207

\section{Terms of Use}

This article was downloaded from Harvard University's DASH repository, and is made available under the terms and conditions applicable to Other Posted Material, as set forth at http:// nrs.harvard.edu/urn-3:HUL.InstRepos:dash.current.terms-of-use\#LAA

\section{Share Your Story}

The Harvard community has made this article openly available.

Please share how this access benefits you. Submit a story.

\section{Accessibility}


The fruits of scientific research are nourished by many roots, including the work of other scientists. Significantly, Albert Einstein himself characterized his work as the "Maxwellian Program." But often the imagination of scientists also draws on a quite different, "extrascientific" source. Indeed, in his own intellectual autobiography, Einstein asserted that reading David Hume and Ernst Mach had crucially aided in his early discoveries. ${ }^{2}$

Such hints point to one path that historical scholarship on Einstein, to this day, has hardly explored-tracing the main cultural roots that may have helped shape his scientific ideas in the first place, for example, the literary or philosophic aspect of the cultural milieu in which he and many of his fellow scientists grew up. ${ }^{3}$ To put the question more generally, as Erwin Schrödinger did in 1932, to what extent is the pursuit of science milieubedingt, where the word bedingt can have the strict connective sense of "dependent on," the more gentle and useful meaning of "being conditioned by," or, as I prefer, "to be in resonance with"? In this Introduction I will explore how the cultural milieu in which Einstein found himself resonated with and conditioned his science.

There are major studies of such milieu resonances for earlier scientists: for example, the effect of the neo-Platonic philosophy on the imagination of seventeenth-century figures such as Kepler and Galileo; the theological interests that affected Newton's work; the adherence to Naturphilosophie that supported the discoveries of Oersted, J. R. Mayer, and Ampère; or the connection between the religious beliefs of the Puritan period and the science of the day, described in the apt metaphor that concludes Robert K. Merton's famous 1938 monograph, 
"The cultural soil of seventeenth century England was peculiarly fertile for the growth and spread of science." 4

But there have thus far been few attempts to take up the influence of the cultural milieu on the scientific advances of twentieth-century physical scientists. The best known may be that of Paul Forman, who more than two decades ago tried to interpret some scientists' presentations of quantum mechanics chiefly as their response to the sociopolitical malaise in the Weimar Republic ${ }^{5}$-although that work has been vigorously disputed by John Hendry, Stephen Brush, and P. Kraft and P. Kroes. ${ }^{6}$ An example of a different sort is in an area in which Max Jammer and I have published, namely, the study of the extent to which Niels Bohr's introduction of the complementarity principle into physics was influenced by his delight in Søren Kierkegaard's philosophical writings, by his courses taken under the philosopher Harald Høffding, and also, as he claimed, by his reading of William James. ${ }^{7}$

But so far there have been few such investigations into wider, intellectual-cultural influences. I have long thought (and taught) that the full understanding of any particular scientific advance requires attention to both content and context, employing the whole orchestra of instruments, so to speak, playing out the many interacting components, without which there cannot be a full description or understanding of a case. But this is rarely done, although this is the middle ground between the extremes of internalistic study of the text alone, on one end, and current excesses of constructivist externalism on the other. Moreover, in tracing the contributions of twentieth-century physical scientists themselves, the bridge from the humanistic aspects of culture to the scientific ones-which carried much traffic in the past-has narrowed and become fragile. This is a deplorable loss, and one that deserves our attention.

The specific case of Einstein demands such attention for at least two reasons: it may serve as an example for studying other major twentieth-century scientists whose work has been nourished by subterranean connections to elements of the humanistic tradition; and it will help us resolve an intriguing paradox that has plagued scholars concerned with the source and originality of Einstein's creativity.

\section{A personal interlude}

Although it is fashionable for scholars to hide assiduously the private motivations and circumstances that initiated a specific research pro- 
gram, in these introductory pages it will be useful to sketch the personal trajectory that caused me to become aware of the puzzling, paradoxical aspects of Einstein's early work.

I can fix the moment at which I was first drawn into this field of research. When the news of Einstein's death on April I 8, I 955 , reached our physics department, my colleagues proposed a local commemoration of Einstein's life and work. Although my own research was chiefly in experimental high-pressure physics, I had also begun to write on topics in the history of science, and so my assignment was to present how Einstein's work had been analyzed by modern historians of science. Little did I know that this suggestion would start me on a search that would change profoundly my life as a scholar.

I discovered to my dismay that modern historians had not studied seriously Einstein's scientific contributions-their roots, their structure, their development, or their wider influence. This was in striking contrast to the volume and distinction of scholarship on the work of scientists of earlier periods, by such giants of the field as Ludwig Fleck, Alexander Koyré, Robert K. Merton, Hélène Metzger, Joseph Needham, Otto Neugebauer, Marjorie Nicolson, George Sarton, and others-not to speak of their predecessors, such as Pierre Duhem and Ernst Mach. I seemed to be in virgin territory. Even among the many Einstein biographies, there were few serious sources. ${ }^{8}$

In truth, at the time of Einstein's death he was still deeply respected, but chiefly by way of ancestral piety, and for his courageous political opposition at the time to McCarthyism, the arms race, and the Cold War. Scientists generally regarded him as having become an obstinate seeker who had wasted his last decades pursuing in vain a unified field theory; as he told a friend, "At Princeton they regard me as the village idiot." Even his general relativity theory began to be widely taught again only after his death. In his last years he had become a ghostly figure-a long way from the image of the vigorous young man, ready for a brilliant career (Figure I).

Today this perception has vastly changed. To be sure, many bubbles are bursting from the deluge of trendy journalism, whose motto in writing on major figures is well summarized in a recent essay on Herman Melville that carried the headline "Forget the Whale-the Big Question Is: Did He Beat His Wife?"9 But among the people at large Einstein's image is perhaps more ubiquitous than ever; and from professional science historians, there is now an increasing flood of good 


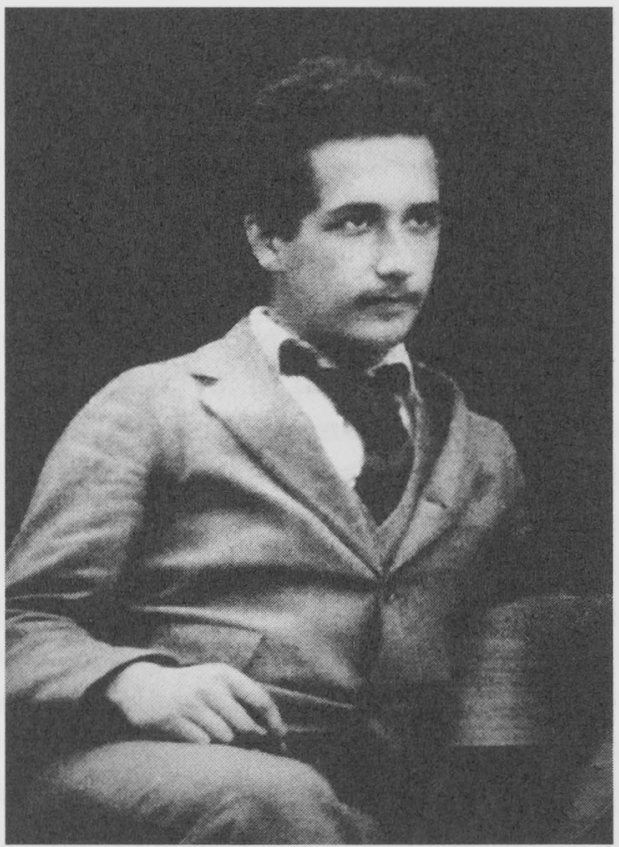

Figure $\mathrm{x}$ : Albert Einstein at age nineteen. (By permission of the Einstein Archive, Hebrew University, Jerusalem.)

scholarship on Einstein, especially since a team of researchers at Boston University has begun to publish the volumes of Einstein's Collected Papers, with their valuable editorial comments providing further stimuli for research.

None of this could have been foreseen in 1955 . In retrospect, I regret not having the wit, as I was drawn into this field, to quote Marie Curie. When asked why she took up the study of radioactivity, she is said to have replied, "Because there was no bibliography." But as the historian Tetsu Hiroshige later commented, somebody had to take a "first step" in research on Einstein; eventually, such an initiative would help launch an industry analogous to the long-established ones on Newton or Darwin. ${ }^{10}$

That first step came in the form of a trip I made to the Institute for Advanced Study in Princeton to look for documents on which to base some original remarks at the memorial meeting. The key to access was 
Helen Dukas, not only a trustee of Einstein's estate, but a woman who had served as his secretary beginning in 1928 and later as general marshall in his household. Knowledgeable about much of his life and work, she was the untiring translator of his drafts into English and, as it turned out, endowed with an encyclopedic memory of the details of Einstein's vast correspondence.

Elsewhere I have described something of my first encounter with Helen Dukas. ${ }^{11}$ In the bowels of Fuld Hall at the Institute was a large vault, similar to those in banks. The heavy door was partly open, and inside, illuminated dimly by a lamp on her desk, was Dukas, still handling correspondence, among twenty or so file drawers that turned out to contain Einstein's scientific correspondence and manuscripts.

Once I had calmed her inborn suspicion about strangers and was allowed access to the files, I found myself in a state of indescribable exhilaration, in a fantastic treasure house-the kind of which most historians dream. Those documents, almost all unpublished, were arranged in a chaotic state through which only Miss Dukas knew her way with ease; they seemed to breathe the life of the great scientist and his correspondents from all points of the compass, a rich mixture of science and philosophical speculation, of humor and dead-serious calculations.

Eventually, during two stays at the Institute, I induced Miss Dukas to help reorganize the papers into an archive suitable for scholarly research, to have a catalogue raisonné made, and by and by to add to the files at the Institute what she called "the more personal correspondence," which she had kept at Einstein's Mercer Street home. The whole lot, now numbering about 45,000 documents, has since been transferred in accordance with Einstein's will to the library at Hebrew University in Jerusalem. Represented in that collection are most major physicists in Europe and abroad of that era, as well as authors, artists, statesmen, and the wretched of the earth, seeking help. The collection is indeed a microscope on half a century of history.

The correspondence is amazingly diverse. Take, for example, the letters exchanged during just one of Einstein's immensely busy and creative periods (1914-1918); they indicate a wide spectrum of interests among the correspondents-mostly scientists — even if gauged just by the references made to the works of major scientific, literary, and philosophical figures, including Ampère, Ludwig Boltzmann, Hegel, Hermann von Helmholtz, Hertz, Hume, Kant, Kirchhoff, Mach, Poin- 
caré, and Spinoza. And one word repeatedly appears in the correspondence-Weltbild, only faintly translatable as "worldpicture" or "worldview." Initially I did not realize how important this concept, and these authors, would become in understanding Einstein's whole research program.

But to return to my mission at the time. How to proceed? In that mountain of papers at Princeton, the question of which problem I would use to start on a historical study was almost irrelevant; wherever one looked, there were exciting possibilities. For example, what role did experiments play in the genesis of the special relativity theory? Like virtually everyone else, I had thought that the Michelson-Morley experiment of I 886 was the crucial influence that led Einstein to the relativity theory. (Indeed, I had just recently published a textbook on physics that had said so.) I had read that opinion everywhere: Robert Millikan, for example, after describing the Michelson-Morley experiment, simply concluded with the sentence, "Thus was born the special theory of relativity." 12

But as samples of Einstein's correspondence soon hinted, it was not so simple. One such warning occurs in his letter of February 9, 1954, to F. G. Davenport: "One can therefore understand why in my personal struggle Michelson's experiment played no role or at least no decisive role." Indeed, I later found that Einstein had repeated his stance over and over again. ${ }^{13}$ In developing the relativity theory, he had typically gone his own way, relying on well-established, much older findingsexperiments by Faraday, Bradley, and Fizeau-saying, "They were enough." 14 The haunting question suggested itself: What helped young Einstein make the leap when other, more established physicists could have done it so much earlier?

\section{Outlining the paradox}

These hasty first glimpses of the products of a creative mind seemed to me at first puzzling, incoherent, and contradictory. They also reinforced the paradox that Einstein, who proudly rebelled against mainstream conventions in science as well as the social and political norms of his time, was also deeply devoted to existing cultural canons. Was this dichotomy a hindrance, or could it possibly be a clue to understanding Einstein's uniqueness in a new way?

Einstein's rebelliousness took the form of disobedience or insubordi- 
nation to authority, a tendency to be obstinately nonconformist, dissident, defiant, and, in a phrase he applied to himself, "stubborn as a mule." That image of Einstein is embedded both in the public perception and throughout the literature. For example, an Einstein biography written jointly by the mathematician Banesh Hoffmann (who once worked with Einstein) and Helen Dukas is entitled Albert Einstein: Creator and Rebel. ${ }^{15}$ Lewis Feuer, in his 1974 book Einstein and the Generations of Science, presented an Einstein whose attitude in life and science was shaped by the countercultural milieu of the young revolutionaries who lived in Zurich and Bern around the turn of the century. ${ }^{16}$ Even the New York Times seemed to view Einstein's general relativity theory as a grave social threat. On November r6, I9I9, under the title "Jazz in the Scientific World," the newspaper reported at length that Charles Poor, a professor of celestial mechanics at Columbia University, thought Einstein's success showed that the spirit of unrest of that period had "invaded science," and the Times added its own warning: "When is space curved? When do parallel lines meet? When is a circle not a circle? When are the three angles of a triangle not equal to two right angles? Why, when Bolshevism enters the world of science, of course." 17

But concentrating only on Einstein's rebelliousness overlooks an entirely different aspect of his persona, namely, Einstein as a cultural traditionalist, even within the limits set by his innate skepticism. If it can be proven that these opposites are combined in Einstein (as I shall show), his type of rebellion would be far from that of our twentiethcentury rebels in art, poetry, politics, academe, or folklore-rebels who typically reject the social-political conventions of the bourgeoisie along with its cultural canon. Moreover, we shall see how Einstein's assertion of obstinate nonconformity enabled him ruthlessly to clear away obstacles impeding his great scientific advance, even though the program of that advance itself ran along one of the oldest traditionalist lines. Skepticism, while necessary, was not enough to build the Temple of Isis, to use the metaphor that had long been current among German scientists. ${ }^{18}$

\section{An excursion into terminology}

In order to understand "the cultural roots of Einstein's science"-especially today, when various definitions of "culture" are violently bat- 
tling for primacy among anthropologists-it is necessary to review some key concepts operative in the German context at the time of young Einstein's formation. The main concepts that are relevant here are Kultur and its companions, Zivilisation and Bildung, as well as the two composite notions of Kulturträger and Bildungsbürgertum.

The German language distinguished more sharply between Kultur and Zivilisation than did the English or French languages between their equivalents. ${ }^{19}$ Although both Kultur and Zivilisation were generally understood in German-speaking Europe as supraindividual, collective phenomena, typically Zivilisation focused on the material and technological aspects of society, while Kultur - as first adapted in the German context by Johann Gottfried Herder-referred to the spiritual and value-related aspects. In extreme cases, Zivilisation was identified with superficial "French reason," Kultur with deep "German soul."20

At the level of the individual, the term Bildung (loosely translated as "intellectual formation," "self-refinement," or "education") referred to the process through which a person could acquire the attitudes and products of Kultur. In turn, the nation's Kultur as a whole was sustained-and advanced at its upper, creative level-by such gebildete individuals. Bildung thus meant much more than job-related training; it defined an ideal of human development. And a chief tool for the young to acquire Bildung at its best, albeit for only a small fraction of the population, was by beginning their study in the Gymnasium, the neo-humanistic secondary school for ages ten to eighteen or so. The students were expected to be thoroughly acquainted with the great German poets and thinkers (the Dichter und Denker) as well as with classics from other cultures, especially of antiquity.

Happily, the team preparing Einstein's Collected Papers has found the curricula at Einstein's Munich schools as well as at his high school in Aarau. A quick scan of a few of the mandatory parts of the canon gives a good impression of how the young minds of Einstein and his cohorts were meant to be shaped. Initially there are readings from the Bible; then Latin enters at age ten, and Greek at age thirteen; Caesar's Gallic Wars and Ovid's Metamorphoses are read; then, under the supervision of Einstein's only beloved teacher, Ferdinand Ruess, he is introduced to poems by Uhland, Friedrich Schiller, Goethe, and others; Goethe's prose poem "Hermann and Dorothea" is studied along with Xenophone's “Anabasis"; and the next year, more Schiller, Herder, 
Cicero, and Virgil. At Aarau, Einstein encountered more of the classics in German, French, and Italian; a typical entry for his course in German in 1896 reads: "History of literature from Lessing to the death of Goethe. Read Götz von Berlichingen." The list ends with Iphigenia and Torquato Tasso.

Such knowledge was intended to contribute to forging a common bond between the gebildete individuals raised on similar Gymnasium curricula throughout German-speaking countries, regardless of the particular professional disciplines they were later to study at the universities, whether law, medicine, the humanities, or science-a preparation for the common understanding of that class, in their conversations, letters, and popular lectures, across specialties and even in their personal relations.

But while the Gymnasium placed heavy emphasis on Latin and Greek and other aspects of "pure" Bildung, it had little concern for the kind of practical knowledge offered in other types of German secondary schools without such attention to classical languages, for instance, the so-called Realschulen (where Einstein's father, Hermann, and uncle Jakob, headed for electrical engineering, had received their secondary education). Needless to say, those other schools were considered to be culturally less valuable; their graduates were generally not considered for university training and hence unlikely to achieve the status of Kulturträger.

Here it is crucial to understand a subtlety in the German concept Kulturträger. The term had a double meaning: both carrier and pillar of Kultur. On the one hand, gebildete individuals-chiefly the graduates of Gymnasium who had gone on to the universities-were seen as carrying or even embodying Kultur, living among its products, and, in the case of the most outstanding individuals, advancing the Kultur. On the other hand, as a group they also functioned as the chief supporters (Träger, pillars) of the nation's collective project of Kultur. Although the term Kulturträger itself became popular only after World War I, it was a key concept earlier, as the following episode illustrates. In I910, a bill in Prussia proposed changing the three-tiered electoral law to favor Kulturträger; they would be put into a smaller pool of voters "above the class for which their wealth would qualify them," so that their votes would count more. ${ }^{21}$

At the level of social stratification, most of the Kulturträger could 
be identified as belonging to what has been called the Bildungsbürgertum (the educated members of the bourgeoisie). The sociologist Karl Mannheim usefully distinguished two components in the modern bourgeoisie: "on the one hand the owners of capital, on the other those whose only capital consisted in their education." 22 In nineteenth-century Germany, the latter formed the Bildungsbürgertum; their social ranks were symbolized by the certificates they had attained during the process of Bildung and often also by a position within the hierarchies of the civil service. Bildungsbürger worked predominantly in professions that required university training, as physicians, lawyers, and clergy, as well as teachers and professors and other, higher officials in government service.

Variants of the Bildungsbürgertum existed in many countries, but its social clout was particularly strong in nineteenth-century Germany. In the context of Germany's relatively backward economy at the time, the importance of serving in the governments of the multitude of German territories large or small favored the prominence of the Bildungsbürgertum over the economic bourgeoisie. Also, in the absence of a nation-state and a centralized economy, German nationalism focused on Kultur as the basis of the nation. What held the conception of Germany together was perhaps chiefly the cultural and scholarly output of its poets and dramatists, thinkers, composers, and, eventually, its scientists. One thinks here of Goethe and Schiller, Friedrich Gottlieb Klopstock, Gotthold Ephraim Lessing, Herder, Friedrich Hölderlin and Johann Joachim Winckelmann (the prophets of Hellenism), Friedrich Schleiermacher, Friedrich Schelling, Friedrich Schlegel, Immanuel Kant, Schopenhauer, and Nietzsche, as well as Bach, Haydn, Mozart, Schubert, and Beethoven.

Thus, the academic elite among the Kulturträger had fundamentally a twofold mission. One was to help secure, through their scholarship, the foundation of German nationhood-although, for most of them, this also involved keeping their distance from political life-and so they tended to be looked up to by those who did not, at least not yet, qualify for that rank. The other mission was chiefly to help prepare a cadre of gebildete individuals, high-level functionaries who were, to adapt Fritz Ringer's terminology, "Mandarins."23

It is ironic that whenever Einstein, after becoming world famous, traveled abroad to lecture, an official from the local German embassy 
or consulate would secretly report to the Foreign Office in Berlin on how Einstein had comported himself and how he had been received. A typical account, now available, would state that Einstein had done well, and Germany would be wise to use him to conduct what one report calls "Kulturpropaganda." ${ }^{24}$ In short, he might yet be put to use as a Mandarin.

As Mannheim noted, there existed among the Kulturträger themselves a small group of "free-floating" (freischwebende) intellectuals who led marginal existences, lacked a well-defined anchor in society, and had rather critical and even rebellious inclinations. They could not or would not share the staid material comforts of the Bildungsbürger and disliked the whole business of "climbing up to the next rung of social existence." 25 With that clarification, we can connect these concepts with the status and hopes of the Einstein family, asking what young Einstein's place was within the cultural-social order of the time.

The Einsteins could trace their origins in southern Germany to the seventeenth century. ${ }^{26}$ On the paternal side of the family, they had mostly come from the small town of Buchau, in Swabia, which in mid-century had some two thousand inhabitants, of whom a few hundred were Jews. On the maternal side, the origins were chiefly in the similarly small Swabian town of Jebenhausen. Einstein's maternal grandfather, Julius Koch, left Jebenhausen for Cannstadt near Stuttgart and became quite wealthy through the grain trade. Einstein's mother, Pauline, thus belonged to the bourgeoisie chiefly by virtue of capital. His father Hermann's preparation in technical school and technical trade-like that of his brother and business partner, the engineer Jakob-also did not quite qualify them as Bildungsbürger, and certainly not as Kulturträger, though one may doubt that Hermann ever gave any thought to that. But at last the family tree had sprouted, in the form of Albert, a promise to grow into that higher social region-if only the bright lad would behave as he should!

We can now reformulate the paradoxical tension of Einstein's tendency toward social-political rebelliousness and his adherence to the products of Kultur. Was he just one of those rootless, rebellious intellectuals, reneging on his mission as a Kulturträger, or did his sympathies lie with the true carriers and pillars of national culture? To make the question more graphic, imagine a scene in which Einstein first stands accused of being a free-floating intellectual intent on undermin- 
ing authority, and then is defended from that charge. The testimonials offered by either side will aid in understanding better the motivations behind Einstein's behavior-and his science.

\section{Chronology of a curious rebellion}

A prosecuting attorney would find it easy to establish, by chronology as well as by psychosociological profile, a portrait of Einstein as a rebellious individual throughout his life. I have no competence for searching for the possible causes of his rebelliousness, but as to the documentable facts, many details are well known, and the pattern they form is persuasive. Einstein made his obstinacy known almost from birth, refusing to speak until about age two and a half, or, as Erik Erikson remarked, until he could begin to speak sensibly in whole sentences. ${ }^{27}$ When Albert reached school age, his penchant for defiance took a different form. In her memoir, his sister Maja reported that in opposition to his thoroughly secular home environment, young Albert decided to become a religious Jew and accordingly "obeyed in all particulars the religious commands," including the dietary ones. ${ }^{28}$ But after he had advanced to Munich's Luitpold Gymnasium and encountered the state-prescribed, compulsory courses on Jewish religion there, Albert's interest in Judaism came to an abrupt end. His reading in scientific books led him, as he put it in his autobiography, to the impression that through organized religious education "youth is intentionally being deceived by the state through lies." He now turned to a "positively fanatic [orgy of] free thinking," having formed a "suspicion against every kind of authority"; he found solace in what he later called his "holy little book of Geometry," which was given to him as a present for self-study - a first hint of where his destiny would lead him. ${ }^{29}$

But as one would expect, he found school life too regimented for his taste, and he dropped out of the Gymnasium at fifteen and a half, surely much to the relief of some of his teachers. About a year later he renounced his citizenship as well. When he moved for his final year of high school to Aarau, Switzerland, he arrived as a thoroughly alienated youth, having left his school, his country, and his family; he even failed in his first attempt to enroll at the Swiss Polytechnic Institute. Once Albert did get into the Polytechnic he continued his "in your face" rebelliousness, to the point that when speaking to his main professor, 
Heinrich Friedrich Weber-on whom his career might well depend-he refused to use the obligatory title and obstinately called him just "Herr Weber." In turn, Weber did nothing to help him in his job search later.

Einstein's lifestyle at the time was distinctly bohemian. ${ }^{30} \mathrm{He}$ lived on the margins of bourgeois society economically, socially, and (by the standards of the day and place) morally; he lived with his fellow student Mileva Marić, who bore their first child before they were married in 1903. To be sure, they passionately loved each other, and as their letters show, they were of one mind in railing against the "philistine" lifestyle and conventions they saw all around them.

Even in Einstein's great paper of 1905 on relativity, one can find many touches of that self-confident defiance and seeming arrogance, with respect not only to accepted ideas in science, but also to accepted style and practice. Thus the paper contained none of the expected footnote references or credits, only a mention of his friend Michele Besso, a person who of course would be unknown among research physicists.

Einstein, who often characterized himself as a gypsy, at first found only temporary teaching jobs, and those tended to end abruptly and noisily. Finally, after the intercession of the father of his friend Marcel Grossmann, he found refuge at the Patent Office. By I909, he began to be sought after by universities and in r9I4 accepted a call to the university in Berlin and the Prussian Academy, chiefly to gain freedom from teaching and other obligations. In fact, he managed to avoid turning out more than a single Ph.D. of his own during his lifetime. ${ }^{31}$ As director of the Institute for Physics, he paid minimal attention to his directorial duties, even as to the recruitment of new members or to drawing up regulations. ${ }^{32}$ "Red tape," he explained, "encases the spirit like the bands of a mummy." When he first met John D. Rockefeller, Jr., the two men compared notes on how to get things done. "I put my faith in organization," Rockefeller said; "I put my faith in intuition," came Einstein's reply. ${ }^{33}$

When war broke out in August 1914, ninety-three of the chief intellectuals of Germany published a manifesto with the significant title "Appeal to the World of Culture," supporting the military. Einstein, for his part, supported a pacifist counterdeclaration entitled "Appeal to the Europeans"; however, it was never published, having attracted a grand total of only four signatures. But throughout the war Einstein never made a secret of his pacifist and cosmopolitan attitude, and in an 
increasingly hostile Germany he took care to express publicly his support for the founding of a Jewish state in Palestine. He also made it plain that he regarded himself again as a Jew and indeed as a religious person; of course, as shown in several essays in his book Ideas and Opinions, his idea of religion was contrary to any religious establishment. It was a Spinozistic pantheism that he called "cosmic religion," and he put his position simply and seriously in one of his letters: "I am a deeply religious unbeliever." 34

When World War II broke out Einstein, who had moved to America, was not kept informed about nuclear research. On the contrary, he was carefully monitored by the military and the FBI, which considered him a security risk. The FBI files on Einstein are voluminous; J. Edgar Hoover apparently was personally convinced that Einstein had to be watched-the physicist's history showed that he was a truly dangerous rebel.

One could add even more weight to the side of the balance that measures Einstein's iconoclastic nature. But if now the defense attorney for the accused is given some moments for rebuttal, a counterargument would be introduced by noting that Einstein's rebelliousness was only half the story-the other half was his selective reverence for tradition. Indeed, the counsel for the defense might well urge us to consider it a hallmark of genius to tolerate and perhaps even relish what seems to us such apparent contradiction.

There were, in fact, significant limits to the offenses cited. For example, one might be more lenient about Einstein's leaving his Gymnasium early, given that he preferred reading classics of science and literature on his own. After all, the school system was by no means beloved by all its pupils-not least because it devoted itself not only to educational goals but also to political indoctrination. Although there were variations among school systems in different parts of Germany, an official Prussian publication was typical in setting forth the plan and aims for the upper schools of 1892 , when Einstein was a Gymnasiast. It announced, "Instruction in German is, next to that in religion and history, ethically the most significant in the organism of our higher schools. The task to be accomplished here is extraordinarily difficult and can be properly met only by those teachers who warm up the impressionable hearts of our youths for the German language, for the destiny of the German people, and for German spiritual greatness. And 
such teachers must be able to rely on their deeper understanding of our language and its history, while also being borne up by enthusiasm for the treasures of our literature, and being filled with patriotic spirit." 35 Clearly, Bildung and Kultur were here instrumentalized in the service of the state. To young Einstein, this program smelled of militarism.

Moreover, when the public and his fellow scientists later hailed him as the great scientific revolutionary, Einstein took pains to deny this label. He emphasized repeatedly that his work was firmly embedded in the tradition of physics and had to be considered an evolution of it, rather than a revolution. He would have been appalled to know that a few years after his death a philosopher would assert that a wall of incommensurability existed between the world of Newton and the world of Einstein.

But points such as these pale in comparison to a central one: Einstein maintained a lifelong interest in and devotion to the European literary and philosophical cultural tradition, and especially to German literary and philosophical Kultur. That allegiance, in which his imagination was embedded, had been fostered early in his childhood. While the classics of music were offered in their home by his mother, Einstein's father would assemble the family in the evening under the lamplight to read aloud from works by such writers as Schiller or Heinrich Heine. ${ }^{36}$ The family perceived itself as participating in the movement of general Bildung, the uplifting of mind, character, and spirit that characterized the rising portion of the Bürgertum, especially its Jewish segments. Kultur advocated and legitimized emancipation, and also provided a vehicle of social assimilation.

After all, during his scientifically most creative and intense period in Bern, Einstein formed with two young friends an "academy" for the self-study of scientific, philosophical, and literary classics. We have the list of the books they read and discussed at their meetings, which sometimes convened several times a week: Spinoza, Hume, Mach, Avenarius, Karl Pearson, Ampère, Helmholtz, Riemann, Richard Dedekind, William Clifford, Poincaré, John Stuart Mill, and Kirchhoff, as well as Sophocles and Racine, Cervantes and Dickens. ${ }^{37}$ Einstein and his friends would not have wanted to be ignorant of the cultural milieu, even if they did not necessarily agree with all they read.

To illuminate the point with but a single example: we know that Albert at the tender age of thirteen was introduced to Kant's philosophy, starting with the Critique of Pure Reason, through his contacts 
with Max Talmey, a regular guest at the Einstein home. ${ }^{38} \mathrm{He}$ reread Kant's book at the age of sixteen, and enrolled in a lecture course on Kant while at the Technical Institute in Zurich. ${ }^{39} \mathrm{He}$ wrote a lengthy book review of a philosopher's analysis of Kant, and at the Institute in Princeton his favorite topic of discussion with his friend Kurt Gödel was, again, Kant. ${ }^{40}$ Einstein surely knew of the overwhelming influence of Kant on, for example, the late-nineteenth-century philosophers arguing against materialism.

All this, typically, did not make Einstein a Kantian at all. While he sympathized with Kantian categories-and was very likely to remember that Kant had listed "Unity" as the first of his categories ${ }^{41}$-Einstein objected to the central point of Kant's transcendental idealism by denying the existence of the synthetic a priori, arguing that the essential point for him was, again, freedom, the "free play" of the individual imagination, within the empirical boundaries the world has set for us. ${ }^{42}$

Thus Einstein's reverence was carefully selective, even while his outreach into the traditional cultural environment was enormous. He loved books, and they were his constant companions. A list of only those books found in the Einstein household at Princeton that had been published up to I9Io includes the works of Aristophanes, Boltzmann, Ludwig Büchner, Cervantes, Clifford, Dante, Dedekind, Dickens, Dostoyevski, Friedrich Hebbel, the collected works of Heine (two editions), Helmholtz, Homer, Alexander von Humboldt (both the collected works and his Kosmos), many books of Kant, Lessing, Mach, Nietzsche, Schopenhauer, Sophocles, Spinoza, and, for good measure, Mark Twain. ${ }^{43}$ But what looms largest are the collected works of Johann Wolfgang von Goethe: a thirty-six-volume edition and another of twelve volumes, plus two volumes on his optics, one on the exchange of letters between Goethe and Schiller, and also a separate volume of the tragedy Faust, which will become a significant part of our story.

Some of those books have such early dates of publication that they may have been heirlooms; others must have been lost in the turmoil of the various migrations and separations. But this list, though only a part of the total library, indicates roughly what aspiring members of the culture-carrying class would want to know about. And their schooling had prepared them, willing or not, to take such exemplars of higher culture seriously, not least as preparation for school examinations.

Einstein's required courses in high school were mentioned earlier; at the Polytechnic Institute, where Einstein was training to be a high 
school physics teacher, he took all the required science courses, including differential equations, analytical geometry, and mechanics-although what he most wanted to learn, Maxwell's electromagnetism, he had to study on his own. In his first year, he enrolled in two additional optional courses, one on the philosophy of Kant, as noted earlier, and one entitled "Goethe, Werke und Weltanschauung." No doubt-he had been captured.

\section{Toward a verdict}

The opposing evidences--Einstein's rebelliousness and his attention to tradition-having now been presented, is not the obvious conclusion that in Einstein we are dealing with a sort of split personality? The answer is No; we have seen two different perspectives of one coherent mental structure that uses the seemingly conflicting parts to support each other.

The bonds between the apparent opposites are of two kinds. The first lies in the presence of an alternative subcurrent in the Kultur itself. As I have hinted, Kultur carried within itself a strain that we may call a "tradition of rebellion," which made it in fact potentially unstable and volatile. The anti-Enlightenment Sturm und Drang and Romantic products of the earlier period had become canonized and remained part of the tradition-bound, late-nineteenth-century Kultur; the ideal of the active, creative, unbounded individual continued to be championed. Such a person had to accept the plain and simple dutyto strive for authenticity and intensity of feeling, even heroism and sacrifice. ${ }^{44}$ The purest expression of individuality was embodied in the genius, who led an often marginal, tormented, and, by conventional standards, failing or even demonic existence but who nonetheless saw and created things far beyond the reach of comfortable philistines. ${ }^{45}$ Those philistines were the enemies for the Sturm und Drang authors, as they were for Einstein.

These two strains in Kultur, the rebellious and the traditional, were often complementary. Those formed by this Kultur were prepared to flout convention, while at the same time revering the outstanding cultural figures of all times. Although willing to dissent, they also understood themselves as loyal members of a supratemporal community of exceptional minds that existed in a universe parallel to that of the philistine masses. This mixture was not considered contradictory, al- 
though note must be taken here of what history was to record later in bloodstained letters: when these elements of rebelliousness later broke away from their stabilizing counterparts in culture, they flamed up for a time in twentieth-century Germany into the transformation and destruction of Kultur itself-as Einstein and so many others were to experience. But during his formative years, this complementary nature of Kultur still functioned, and it was precisely what Einstein needed for his work and life.

The second of the three bonds connecting those seemingly contradictory aspects of Einstein lies, unsurprisingly, in his approach to physics, both in his manner of radically clearing obstacles and in how he achieved his insights with the aid of tools from the traditional culture. Looking at his papers and letters, one can almost watch the seemingly centrifugal tendencies of Einstein's spirit being used and tamed to his service. I found the first hint in the letter he wrote in the spring of 1905 to his friend Carl Habicht. ${ }^{46}$ In a single paragraph, Einstein poured out an accounting of major works he was then completing. First on his list was the discovery of the quantum nature of light, which explained the photoelectric effect. Another was his prediction and detailed explanation of a random, zigzag movement of tiny objects in suspension that might be watched through a microscope; in that work he would trace the cause in exact detail to the bombardment of these visible bodies by the invisible submicroscopic chaos of molecules all around them. (The existence of such motion, referred to as Brownian movement, was known but not understood.) And the last of the papers-in-progress that he referred to was what became the original presentation of Einstein's relativity theory, identifying that work to Habicht only as an evolutionary act, "a modification" of current teachings. To achieve that, in the published paper he casually discarded the ether, which had been preoccupying the lives of a large number of prominent physicists for more than a century, with the nonchalant remark that it was "superfluous"; dismissed the ideas of the absolutes of space, time, and simultaneity; showed that the basic differences between the two great warring camps, the electromagnetic and mechanistic worldviews, were dissolved into a new, relativistic worldview; and finally, as an afterthought, derived $\mathrm{E}=\mathrm{mc}^{2}$.

Each of these papers, completed in 1905 , is a dazzling achievement, and, what is more, they always have seemed to be in three completely 
different fields. But I could not rid myself of the thought that behind their obvious differences something common was motivating these articles, which were published rapidly, one right after the other. Something was missing in that exuberant letter to Habicht.

An important lead was found at last in an unpublished letter Einstein had written to Max von Laue in January 1952, which indicates the hidden connection. ${ }^{47}$ This point will be elaborated in Chapter 3, but to put it very briefly, Einstein's study of Maxwell's theory, which had led him to the theory of relativity, had also convinced him that radiation has an atomistic (that is to say, quantum) structure, exhibiting fluctuation phenomena in the radiation pressure, and that these fluctuations should show up in the Brownian movement of a tiny suspended mirror. Thus the three separate fireworks-relativity, the quantum, and Brownian movement-had originated in a common cartridge.

Moreover, once this is understood, Einstein's approach to the problem in each of these diverse papers could be recognized as having essentially the same style and components. Unlike most other physicists of the time, Einstein began, not by reviewing puzzling new experimental facts, the latest news from the laboratory, but rather by stating his dissatisfaction with what seemed to him asymmetries or other incongruities that others would dismiss as being merely aesthetic in nature. He then proposed a principle of great generality, analogous to the axioms Euclid had placed at the head of that "holy" geometry book. Next Einstein showed in each case how to remove, as one of the deduced consequences, his original dissatisfaction; and at the end, briefly and in a seemingly offhand way, he proposed a few experiments that would bear out predictions following from his theory. Once more there was only one Einstein, not three.

Most significant, the fundamental motivation behind each paper was really the very same one he had announced five years earlier in a letter to a friend, in which he revealed what would become his chief preoccupation in science for the rest of his life: "To recognize the unity of a complex of appearances which . . seem to be separate things." Thus, the paper on the quantum nature of light begins with a typical sentence: "There is a deep formal difference between the theoretical understanding which physicists have about gases and other ponderable bodies, and Maxwell's theory of electromagnetic processes in the so- 
called vacuum." 48 That is to say, the energy of palpable bodies is concentrated, but as a light wave spreads out, its energy in a given area on the wavefront constantly decreases. Why should atomicity not apply to both matter and light energy? The Brownian movement article declared that if there is chaotic motion or spontaneous fluctuation in the microcosm of classical thermodynamics, it must also show up in the macrocosm of visible bodies. And the relativity paper in effect removed the old barriers between space and time, energy and mass, electromagnetic and mechanistic worldviews. In the end, all these papers endeavored to bring together and unify apparent opposites, removing the illusory barriers between them.

\section{Thematic presuppositions}

The longer I studied the papers and correspondence of this scientist, the more impressed I became by his courage to place his confidence, often against all available evidence, in a few fundamental guiding ideas or presuppositions, which he called "categories" in a non-Kantian sense, that is, freely chosen. In studying other major scientists, I have repeatedly found the same courageous tendency to place one's bets early on a few nontestable but highly motivating presuppositions, which I refer to as themata. In Einstein's case, an example of themata would be simplicity, harking back to Newton's first rule of philosophy: "Nature is pleased with simplicity, and affects not the pomp of superfluous causes." ${ }^{49}$ Einstein believed deeply in the concept of simplicity as a guide in science (see Chapter I), and he exemplified it in his own lifestyle.

Another of his thematic presuppositions was symmetry, a concept he introduced into physics in 1905 , considering it basic-when most of his readers surely wrote it off as an aesthetic, optional choice. It has since become one of the fundamental ideas in modern physics. Yet another thema was his belief in strict Newtonian causality and completeness in the description of natural phenomena, which explains why Einstein could not accept as final Niels Bohr's essentially probabilistic, dice-playing universe. Einstein's utter belief in the continuum was yet another such thema, as in the field concepts that enchanted him from the moment he saw his first magnet compass in boyhood.

There are a few more themata to which he also clung obstinately. 
But beyond that, we must ask a key question: Because the themata are not a priori or innate but choosable, are those that are selected chosen at random, from some infinite set of possible themata? That I do not believe. Or are the themata so confidently held because they are reinforced by, and in resonance with, the scientist's cultural milieu? That was the initial question here, but now it can be tested in a real case.

One thema that was the most important to Einstein-that of unity, unification, wholeness-will serve as the prototypical example to answer the question whether themata in science may be reinforced by the cultural milieu. ${ }^{50}$ Einstein's dedication to the presupposition of finding unities in Nature is evident as the motivation for his three great papers of 1905 , and indeed continued uninterrupted from his first paper on capillarity to his last ones on finding a general unified field theory that would join gravity and electromagnetism, as well as providing a new interpretation of quantum phenomena-as may yet happen, although along a path different from his. ${ }^{51}$ In between, that preoccupation had led him from the special theory to what he at first called typically the verallgemeinerte, the generalized theory of relativity. And it was for him not only a scientific need to view the world of separate phenomena as expression of one great unity; it was for Einstein also a psychological necessity. As he put it in one of his essays on Cosmic Religion, "The Religious Spirit" (1934): "Individual existence impresses one as a sort of prison, and one wants to experience the universe as a single significant whole."

That self-imposed, unquenchable desire to find unifying theories had possessed many other scientists (for example, Alexander von Humboldt, who celebrated in 1828 the "deep feeling for a unity of Nature," and who in his Kosmos [1845, pp. 5-6] declared: "Nature is unity in multipicity. ... The most important result of thoughtful physical research is to recognize unity in variety"). To be sure, this presupposition sometimes led Einstein astray, as had Galileo's analogous obsession with the primacy of circular motion. And some splendid science is done by researchers who seem to have no need at all of thematic presuppositions, as I have found in other case studies. Nor do I want to paint all German scientists as having been caught up in the dream of unity; for example, as Pauline Mazumdar's study of German immunologists showed, there were "Pluralists" among them to oppose the "Unitarians." 52

But my subject is Einstein, and it is clear that his thematic accep- 


\section{Gufruf!}

Eine umfassende Weltanschauung auf Grund des Tatsachenstoffes vorzubereiten, den die Einzelwissenschaften aufgehăuft haben. und die Ansătze dazu zunâchst unter den Forschern selbst zu verbreiten, ist ein immer dringenderes Bedûrfnis vor allem für die Wissenschaft geworden, dann aber auch fûr unsere Zeit ûberhaupt, die dadurch erst erwerben wird. was wir besitzen.

Doch nur durch gemeinsame Arbeit vieler kann das erreicht werden. Darum rufen wir alle philosophisch interessierten Forscher, auf weichen wissenschaftlichen Gebieten sie auch betâtigt sein mogen, und alle Philosophen im engeren Sinne, die zu haltbaren Lehren nur durch eindringzndes Studium der Tatsachen der Erfahrung selbst zu gelangen hoffen, zum Beitritt zu einer Gesellschaft fûr positivistische Philosophie aut. Sie soll den Zweck haben, alle Wissenschaften untereinander in lebendige Verbindung zu setzen, überall die vereinheitlichenden Begrifle zu entwickeln und so zu einer widerspruchsfr zien Gesamtauffassung vorzudringen.

Um nâhere Auskunit 'wende man sich an den mitunterzeichneten Herrn Dozent M. H. Baege. Friedrichshagen b. Berlin, Waldowstraße 23.

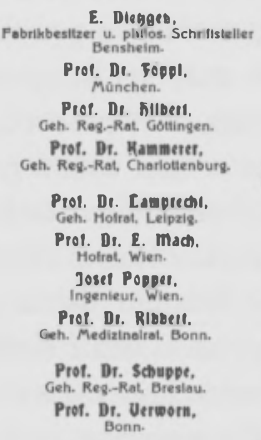

Prot. Di. Elnsteln.
Prag.

Prot. Dr. S. Jreud,

Prot. Di. Jensen.

Gottingen.

Prot. Di. B. Kern. Obergeneralorzt u. Inspekteur
det II. Sontlats-Inspektion, Berlin.

Prot. Dr. O. Lisze.

Geh. Justizrat, Berlin.

Prof. Dr. 6. E. muller,
Gch. Reg-Rot Gottinģen.

Prot. Di. Poloní,
Kanigl. Landesgeologe. Berlin.

Piot. Di. Rour.

Geh. Medizinaliat, Halle o. S.

Prol. Dr. Riller o. Seellger.

Prof. Dr. Wernicke,

Oberrealschuldirelictor, u.
Prival-Dozent, Braunschweig.

Piol. be. Th. Zlehen.

Geh. Medizinalrat. Wiesbaden.
Prot. Dr. ForrI
Yvorne.

Prot. Dr. Felm. Geh. Hotrai, Dresden. Prof. De. Jerusalem. Wien.

Prot. Di. F. Mlein,
Geh. Reg-Rat, Gottingen.

Piot. Di. Coes. Rocketeller-Institute. New-York.

Dr. maller-Luer. Manchen.

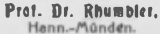

Prof. Di. J. e. S. Salliler.

Corpus Christi College.

Prot. Di. Connles. Kie.

Piot. Di. Wienci.

Figure 2: Appeal for the formation of the Gesellschaft für positivistische Philosophie. (Courtesy of Wilhelm-Ostwald-Archiv, Deutsche Akademie der Wissenschaften zur Berlin.)

tance of unity or wholeness was one of the demons that had got hold of the central fiber of his soul. He even lent his name-along with thirtytwo other distinguished scholars from a variety of fields, ranging from mathematics to biology, and from biology and philosophy to psychology - to the publication, as early as I9 I 2, of a public manifesto ( $A$ ufruf, Figure 2) calling for the establishment of a new Society aiming to develop, across all branches of scholarship, one set of unifying ideas and unitary conceptions. As the Aufruf put it in its second paragraph, 
the new Society's aim would be "to join all fields of learning [alle Wissenschaften] together in an organic association, to develop everywhere the unifying ideas, and thus to advance to a non-contradictory comprehensive conception." $\$ 3$

Yet if it was allegiance to a few themata that supported Einstein in launching into uncharted territory, often with the barest encouragement from the phenomena, what provided the courage to adopt these themata, and to stick with them through thick and thin? This is where the various strands we have pursued will converge, where we make closest contact with the "cultural soil" that helped to feed his scientific imagination; for one can show the resonance between Einstein's thematic belief in unity in science and the belief in the primacy of unity contained in certain literary works to which he had allegiance. While here I can demonstrate the case for only one of his themata, and for one set of major literary works, the case made is more general and applies to many of the most creative scientists.

\section{The cultural roots of unity: a poet points the way}

So far, we have noted that Einstein drew on the work of other scientists, on the tools of his trade that he assembled during his educationso joyfully by himself, less so in his schooling. We have discussed his personal attitude as a gebildete individual who refused to be a mere functionary of the state and kept his freedom of imagination and destiny. Other useful suggestions for pieces of the puzzle have also been proposed, for example, the interesting point made by Robert Schulmann and Jürgen Renn that Einstein's reading in popular scientific books as a boy consisted largely of works that did not dwell on details but instead provided an overview of science as a coherent corpus of understanding, and that this experience predisposed him early to fasten upon the big questions rather than upon the small pieces. ${ }^{54}$

All this was necessary; but it was not enough. Einstein's wide reading in humanistic works beyond science-where the Bildung during his formative years was to lead to continued self-refinement through study of the "best works," analogous to Matthew Arnold's concept of culture--hinted at what else is needed to understand his particular genius. ${ }^{55}$ From the list of icons of high culture at the time who greatly impressed Einstein, I must focus on just one author, who, with Schiller, was among the most universally revered: Johann Wolfgang von 
Goethe. ${ }^{56}$ Since Goethe is today certainly not on everyone's mind, I will attempt to convey in a few words his unimaginable influence at the time, not merely on educated Germans in general, but on German scientists in particular. ${ }^{57}$

There are two major parts to that influence. One was the fact that Goethe was arguably Germany's most accomplished and productive poet. He began his long and fruitful career when, as noted, Germany was not a modern state. Indeed, in many ways it was backward compared with Britain and France; it was politically impotent, a motley assembly of about three hundred fragments, large and small, within the dying Holy Roman Empire. In 1775 , when the twenty-six-year-old Goethe arrived in Weimar, it was still an impoverished duchy, and his own youthful presence there was possibly one of its biggest assets. His skill, intelligence, and humanity had begun to show themselves even in his first, fiery works that were still linked to the Sturm und Drang tradition, for example, the irreverent revolutionary drama Götz von Berlichingen, written at age twenty-four, and the romantic novel The Sorrows of Young Werther, written one year later. The Götz drama was based on a legendary early sixteenth-century German knight, a bold and impudent adventurer who made it known to all, in strong language, that he was beholden to no one but God, Kaiser Maximilian, and his own independent self. (I find it delightful that during Einstein's final Matura examination, his essay in the subject of German was on $G o ̈ t z$, the very embodiment of the independent individual spirit. ${ }^{58}$ )

Goethe, too, was a complex of apparent opposites. In his early works he had established himself as the foremost German spokesman for the Sturm und Drang movement, the forerunner of the Romantic revolt, while still adhering to Enlightenment ideas. And he was still in his twenties when he began work on the first part of his Faust, the tragedy into which he poured his superb poetic skills and all the varied and mutually antagonistic aspects of his maturing soul. It was, like much of his writings, part of a "great confession," but it had an especially strong grip on the German imagination, on the upward-striving bourgeoisie as well as on the elite; the nearest analog that comes to mind is the indelible impression of Dante's epic on intellectuals in Italy. As G. H. Lewes remarked, the Faust tragedy "has every element: wit, pathos, wisdom, farce, mystery, melody, reverence, doubt, magic, and irony." 59

In his early period, Goethe himself, like his Faust, accepted the 
dictum "To live, not to learn." But as he matured, this rebellion took a special form, similar to Einstein's own. Goethe's central tenet was the belief in individuality or individualism: one was a free person, defying some of the social conventions, but at the same time revering the geniuses of history and legend, which for him (according to Goethe's biographers) included the original Dr. Johann Faustus of the sixteenth century, Prometheus, Spinoza, Mohammed, Caesar, and the original knight Götz von Berlichingen. ${ }^{60}$ Like Spinoza, Goethe saw God and Nature as two aspects of the same basic reality, and in that belief, too, he shared the spirit of Einstein and other scientists. Among German Kulturträger, Goethe became a fascinating and inexhaustible part of their imaginative lives. ${ }^{61}$

I will return to that point in a moment. But it must be noted that a second aspect of Goethe's power was his position as a serious and productive scientist on certain topics, such as the investigation of the subjective impression of color; the discovery, in his first scientific paper, of the presence of an intermaxilliary bone in man; his early version of what Ernst Haeckel later called an "evolutionary mechanism"; his concept of the metamorphosis of plants; and other such matters. Thus Goethe has an honored place even in the modern Dictionary of Scientific Biography, and despite the controversy about some of his other contributions, especially on the theory of colors (the Zur Farbenlehre of $\mathrm{I} 8 \mathrm{IO}$ ), his scientific activities-totaling fourteen volumes of the Weimar edition of his collected works - added to his standing as a figure representing the best of culture in all its dimensions.

To be sure, Goethe's science was chiefly that of the poet-philosopher. Indeed, one early "scientific" essay, entitled "Study after Spinoza," begins with the sentence, "The concept of being and of completeness is one and the same"; from this, Goethe goes on to ponder the meaning of the infinite. ${ }^{62}$ But significantly, the main point of that work was to argue for the primacy of unity in scientific thinking, and for the wholeness "in every living being." The sorry and misguided war he waged for more than four decades against Newton's ideas, especially on color theory, must be understood in terms of Goethe's philosophical and poetic beliefs. For example, the quantification and subdivision of natural phenomena, he thought, missed the whole point of the organic unity of man and nature in the explanation of phenomena, particularly for what he regarded as qualities, such as colors. This is a prominent aspect of much of Goethe's whole corpus: the theme of unity, whole- 
ness, the interconnection of all parts of nature. Those are main conceptions that informed both his science and his epics. As one of his commentators has observed, "The nature of the entire cycle [is this]: unity in duality." ${ }^{63}$ This maxim pervaded even his belief in the existence of an original, archetypal plant (Urpflanze), an archetypal man, and so onall part of what has been called the Ionian Fallacy: looking for one overarching explanation of the diversity of phenomena. ${ }^{64}$ Even at age eighty-one, he was immensely excited by news that in France, the biologist St. Hilaire had associated himself with the concept of unity at the base of biology, and he exclaimed:

What is all intercourse with Nature, if we merely occupy ourselves with individual material parts, and do not feel the breath of the spirit which prescribes to every part its direction, and orders or sanctions every deviation by means of an inherent law! I have exerted myself in this great question for fifty years. At first I was alone, then I found support, and now at last, to my great joy, I am surpassed by congenial minds. ${ }^{65}$

Much has been written about the interest among scientists in various aspects of Goethe's work, and not only in Germany. A list of such scientists would contain names such as Johann Bernhard Stallo, Wilhelm Ostwald, the physiologist Arnold Adolphe Berthold, the neurophysiologists Rudolf Magnus and Emile du Bois-Reymond, the botanist Gottlieb Haberlandt, the physical chemist Gustav Tammann, the bacteriologist Robert Koch, the psychologist Georg Elias Müller, and the English scientist William Henry Fox Talbot. A curious case is that of Nikola Tesla, who, although not German by descent, was so caught up in the German style of Bildung that he claimed, and sometimes demonstrated, that he knew the whole of Goethe's Faust by heart-all I 2, I 10 lines. 66

Of course not everyone shared Tesla's enthusiasm. Many a scientist had to give lip service to Goethe's dominance while actually fighting for a down-to-earth, pragmatic, properly experimental style of thought. But wherever these readers turned, from their school days on, they, like Einstein, were likely to encounter Goethe, and so were liable to absorb and sympathize with that central point in Goethe's work, the longing for unity, for wholeness, for the interconnectivity of all parts of nature. As Walter Moore put it in his biography of Schrödinger, "All German-speaking youth [were] imbued with the spirit of Goethe. . . . They have absorbed in their youth Goethe's feeling for the unity of 
Nature." ${ }^{77}$ Fragments of Goethe's poetry could be encountered routinely, not only in the popular lectures of other Kulturträger or in the exhortations of politicians, but even in the lectures and textbooks on science itself, in the writings of physicists such as Helmholtz, Schrödinger, Wilhelm Wien, and Max Born. Thus Arnold Sommerfeld, in the third volume of his Lectures on Theoretical Physics, sends his readers on general relativity theory off with a quotation from Faust, part II. ${ }^{6}$

My favorite example of that ubiquity occurs on two pages of a textbook by one of Einstein's own scientific predecessors, one whom in 1900 he had called "quite magnificent." ${ }_{69}$ Boltzmann's Vorlesungen über Maxwells Theorie der Elektricität und des Lichtes was published in two parts (I891 and I893), each preceded by a short epigraph. Boltzmann could count on every German reader to recognize the origin of the lines he quoted there, for they referred to the early pages of Goethe's Faust tragedy. The following is my free translation of the first passage: "That I may no longer, with sour labor, have to teach others that which I do not know myself." Boltzmann does not even have to add the next, most celebrated and programmatic lines of Faust: "and that I may perceive what holds the world together in its innermost."

Boltzmann's second epigraph refers to the passage where Faust, on opening the book of Nostradamus to seek even there a guide to the force that holds the world together, is struck by the wondrous "Sign of the Macrocosmos" and exclaims: "Was it a God who designed this hieroglyph ... ? Into one Whole now all things blend."

More on this point will be said in Chapter $\mathrm{I} 2$. But by referring to the God-like signs Boltzmann meant of course to hint that his reader is about to be initiated into the spell of Maxwell's equations, the summary of Maxwell's synthesis of electricity, magnetism, and optics. The equations relating the electric and magnetic field terms are indeed stunningly beautiful in their simplicity, scope, and symmetry, particularly when written in modern form:

$$
\begin{array}{ll}
\text { curl } \mathrm{E}=-\frac{1}{c} \frac{\delta \mathrm{B}}{\delta t} & \operatorname{div} \mathrm{E}=0 \\
\operatorname{curl} \mathrm{B}=\frac{1}{c} \frac{\delta \mathrm{E}}{\delta t} & \operatorname{div} \mathrm{B}=0
\end{array}
$$

It is significant that in both epigraphs Boltzmann's version of Goethe's lines are in fact just a bit wrong. ${ }^{70} \mathrm{He}$, too, was no doubt 
quoting from memory, going back to school days. Used constantly, such verses tend to be taken for granted and get fuzzy at the edges. Boltzmann's errors are really one sign that Goethe's lines have become part of common culture.

We must dig a bit deeper to see why such literary allusions were so meaningful to the scientific reader. Consider the context of those lines, near the beginning of the first part of the Faust tragedy. Having painfully worked his way through every major specialty, Faust finds that his thirst for knowledge at its deepest level has not been satisfied by these separate (let us say, non-coherent) studies-any more than were the signers of the I 9 I 2 Aufruf, calling for unity throughout all sciences and scholarship. Even if he has to turn to the realm of the magical, Faust must discover the secret of the world's coherence. Nostradamus's book offers him the blinding revelation in terms of the Sign of the Macrocosmos, that ancient symbol of the connection between the part and the whole, man and nature (Figure 3). This is why Boltzmann connects the passage to Maxwell's equations that express the synthesis of large parts of physics. ${ }^{71}$

The main point here is the strong resonance between the Goethean or Faustian drive toward a unified fundamental understanding of nature and that of the analogous ambition of Boltzmannian scientists and their pupils: the search for one single, totally coherent worldpicture, a Weltbild encompassing all phenomena. Physical science yearned to progress by the discovery of ever fewer, ever more encompassing fundamental concepts and laws, so that one might achieve at last what Max Planck called, in the title of his 1908 essay, "Die Einheit des physikalischen Weltbildes." 72 Indeed, some physical scientists still work toward the day when one single equation will be found that will subsume all the diversity of physical phenomena. Then the Sign of the Macrocosmos will indeed stand before our gaze.

Einstein, starting with his very first publication in $190 \mathrm{r}$ on capillarity, was committed to an early stage of such a Faustian plan. In that paper he tried to remove a duality between Newtonian gravitation, which directs the motion of macroscopic objects downward, and capillary action, which drives the molecules of the submicroscopic world of the liquid upward. In its way this was also a search for the commonality between the macrocosm of observable gravitation and the microcosm of molecular action. Here was a case where, he thought, apparently opposite phenomena could be brought into a common vision. Even though Einstein later dismissed the physics he had used in that 


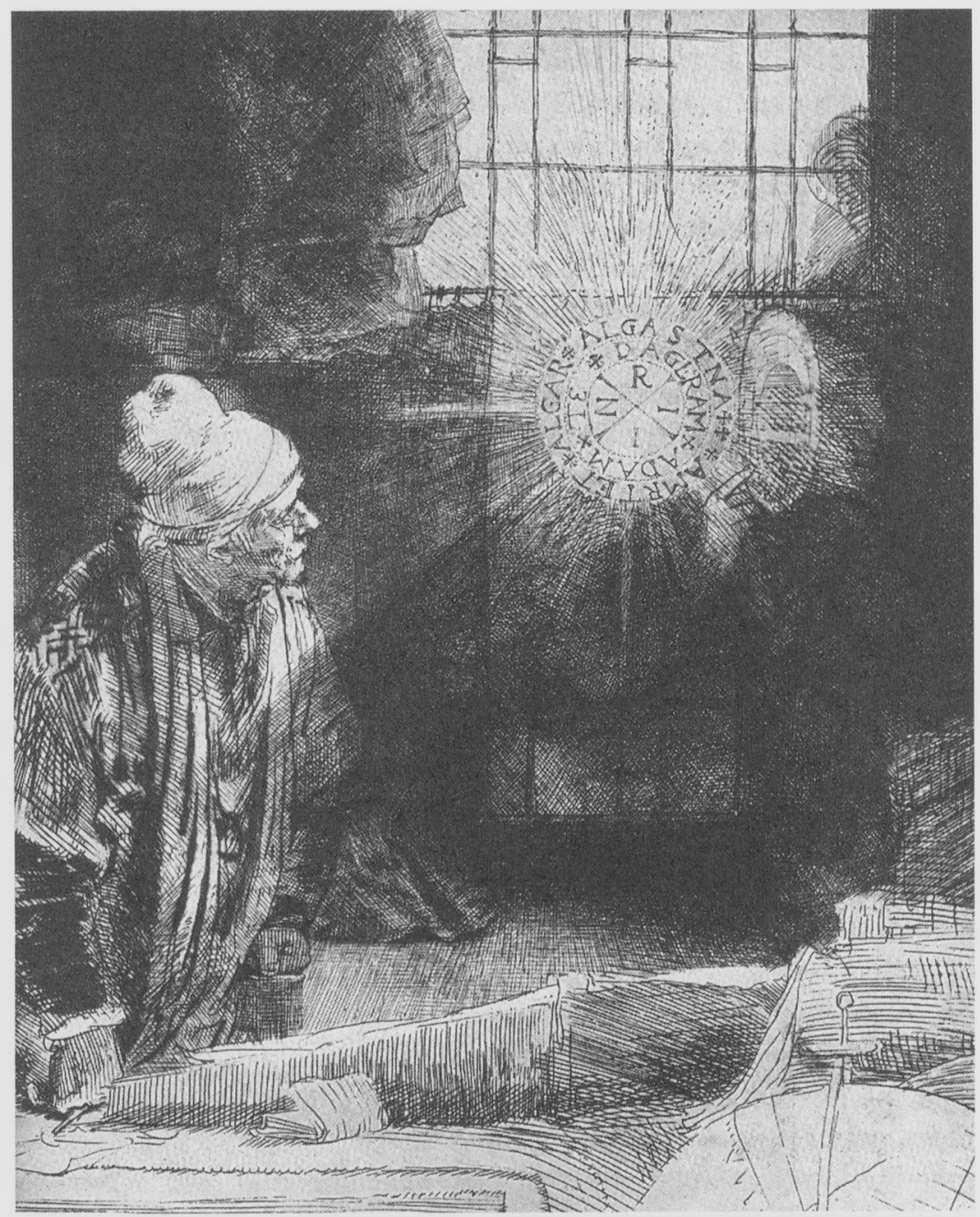

Figure 3: Rembrandt's etching, called “Dr. Faustus" (detail). From L. Münz, ed., Rembrandt's Etchings (London: Phaidon Press, I972).

first paper as juvenilia, he never turned his back on the inherent goal.

The intensity of the impulse toward a unified Weltbild (detailed in what follows, especially in Chapters I and 4) was typical for many German scientists of the time- even while specialization was rising all around them. But it was not confined to them. David Cassidy has noted that 
the "unifying spirit," as it was called, pervaded much of central European thought at the turn of the century. German idealism, neo-Romanticism, and historicism, stretching from Immanuel Kant and Georg Wilhelm Hegel to Benedetto Croce and Wilhelm Dilthey, each pointed to some sort of transcendent higher unity, the existence of permanent ideas or forces that supersede or underlie the transient, ephemeral world of natural phenomena, practical applications, and the daily struggle of human existence. The scholar, the artist, the poet, the theoretical physicist all strove to grasp that higher reality, a reality that because of its permanence and transcendence must reveal ultimate "truth" and, hence, serve as a unifying basis for comprehending, for reacting to, the broader world of existence in its many manifestations. $^{73}$

I can only add in closing that movements as different as turn-of-thecentury Monism, and later the "Unity of Science" movement, were closely related to this set of aims and ideas. And as Anne Harrington has shown in her recent book, the "holistic biological impulse" in early-nineteenth-century Germany later flourished with the assistance of our poet. As she put it, “Goethe's resulting aesthetic-teleological vision of living nature would subsequently function as one of the later generations' recurrent answers to the question of what it 'meant' to be a holistic scientist in the grand German style." 74

At the end of Einstein's century, many excellent scientists and some philosophers would readily settle for a hierarchical or "disunited" science rather than participate in the pursuit of overarching unities. ${ }^{75}$ To them, the self-imposed task of those earlier culture-carriers in search of grand unifications appears perhaps overreaching, and even discussing it as a historic fact may be written off as nostalgia. Moreover, many modern evolutionary biologists and naturalists have insisted that the chief guiding concept should be diversity rather than unity. Perhaps Henry Adams was right when he wrote that after the nineteenth century the course of all history would be away from unity and toward multiplicity and fragmentation. ${ }^{76}$

Yet the fundamental motivation of Einstein's program has helped to keep alive the modern idea of a search for a physical theory that will encompass all phenomena, from gravitation through nuclear science (a path that Einstein himself had not explored). The ascent to that Mt. 
Everest is now taking various forms among different camps, along different routes. The physics journals and even the daily papers are witnesses; and the International School of Physics has announced a physics seminar at Lake Como with the title, in part, "A Probe of Nature's Grand Design." I have little doubt that hovering there above the audience will be a throng of kindred ghosts, including Kant, Maxwell, Boltzmann, and Einstein, and of course, among the poets, Goethe, with Faust himself at his side, and, way in back, the Greek philosopher Thales of Miletus in Ionia, who twenty-six hundred years ago had launched that Ionian dream, the thema that all things are made of one essence. All those forebears had tilled and seeded the cultural soil of their time and, in turn, in their different ways, had been nourished and reinforced by it.

\section{Ashes into the winds}

When death approached to claim Einstein in April 1955, his last acts were still fully in character. He remained strong-willed to the end, obstinately adhering to his ways. He had recently signed a manifesto with Bertrand Russell and others calling on the international community of scientists to act as a unifying counterweight against the divisive, national ambitions then rampant during the arms race. For seven years, Einstein had known that a growing intestinal aneurysm of his aorta might rupture at any time, but he had refused any major operation when it still might have averted the threat. He explained his uncomplaining state of mind to his stepdaughter Margot by saying simply, "I have done my thing here." At about one o'clock in the morning, as the aneurysm burst, he suddenly spoke once more. But the night nurse did not understand German.

Einstein's requests concerning his last rest also bore all the marks of his lifelong struggle for simplicity and against ordinary convention. There was to be no funeral-only a few family members and friends gathering at the crematorium. No speeches, no flowers, not even music. No gravestone. But as Einstein's ashes were dispersed into the winds, an old friend and fellow émigré felt moved to recite a few verses of poetry, ending with these lines:

He gleams like some departing meteor bright, Combining, with his own, eternal light. 
As it happened, the poem had been written a century and a half earlier by the grief-stricken Goethe in memory of the death of his friend Friedrich Schiller. A great circle had closed. Symbolically, Einstein's lifelong comrades had helped him, once more, to move across those illusory divisions between space, time, and cultures.

\section{NOTES}

This Introduction is based on the Robert and Maurine Rothschild Distinguished Lecture in the History of Science, Harvard University, April 8, 1997. I wish to acknowledge several colleagues whom I have consulted on aspects of this work, including Gordon Craig, Frederick Gregory, Roald Hoffmann, Robert Schulmann, S. S. Schweber-none of whom are responsible for possible errors-and, above all, Gerhard Sonnert, who provided essential and dedicated help throughout. I am grateful to the Andrew W. Mellon Foundation for support of a research project of which this essay is part.

I. It is symbolic that among the framed portraits he kept in his Princeton home there were only three scientists, each of whom pursued a great synthesis in physicsNewton, Faraday, and Maxwell.

2. Albert Einstein, "Autobiographical Notes," in Albert Einstein: Philosopher-Scientist, ed. Paul Arthur Schilpp (Evanston, Ill.: Library of Living Philosophers, 1949), 53 .

3. Looking in the opposite direction, that is, at how cultural elements later were affected by relativity theory rather than initially helping to shape it, we know that certain of Einstein's publications were interpreted to affect the culture of his and our time, misguided though most of these attempts have been-as Steven Weinberg recently warned-such as the transfer of relativity concepts into anthropology, ethics, religion, literature, and the so-called relativism haunting other fields. Einstein himself was perturbed by popular misunderstanding of his theory. He would have preferred that his theory-which Max Planck and Max Abraham, not Einstein himself, had named the "theory of relativity"-become known as the "theory of invariance" instead. Einstein, letter to E. Zschimmer, September 30, r92 I; cf. Gerald Holton, Einstein, History, and Other Passions: The Rebellion against Science at the End of the Twentieth Century (Reading, Mass.: Addison-Wesley, 1996), I 3 I-I 32. See also Steven Weinberg, "Sokal's Hoax," New York Review of Books, August 8, 1996, II-1 5.

4. Robert K. Merton, Science, Technology, and Society in Seventeenth Century England (New York: H. Fertig, r970; first published 1938), 238.

5. Paul Forman, "Weimar Culture, Causality, and Quantum Theory, I918-1927: Adaption by German Physicists and Mathematicians to a Hostile Intellectual Environment," Historical Studies in the Physical Sciences 3 ( 197 I): I-I I 5. 
6. John Hendry, "Weimar Culture and Quantum Causality," History of Science 18 (1980): I 55-1 80; Stephen G. Brush, "The Chimerical Cat: Philosophy of Quantum Mechanics in Historical Perspective," Social Studies of Science ro (1980): 393-447; P. Kraft and P. Kroes, "Adaption of Scientific Knowledge to an Intellectual Environment: Paul Forman's 'Weimar Culture, Causality, and Quantum Theory, 1918-1927," Centaurus 27 (1984): 76-99.

7. Max Jammer, The Conceptual Development of Quantum Mechanics (New York: McGraw-Hill, 1966); Gerald Holton, Thematic Origins of Scientific Thought: Kepler to Einstein (Cambridge, Mass.: Harvard University Press, 1973, 1988).

8. Specifically: Philipp Frank, Einstein: Sein Leben und seine Zeit (Munich: Paul List, 1949), published in English as Einstein: His Life and Times, tr. George Rosen, ed. Shuichi Kusaka (New York: Alfred A. Knopf, 1947); Anton Reiser (pseud. of Rudolf Kayser), Albert Einstein: A Biographical Portrait (New York: Albert and Charles Boni, 1930); and Carl Seelig, Albert Einstein: Eine Dokumentarische Biographie (Zurich: Europa Verlag, 1954). One must include as well Einstein's own fascinating intellectual autobiography, in Schilpp, Albert Einstein: Philosopher-Scientist.

9. New York Times Sunday Magazine, December I 5, 1996.

I0. Tetsu Hiroshige, "The Ether Problem, the Mechanistic World View, and the Origin of the Theory of Relativity," Historical Studies in the Physical Sciences 7 (1976): 3-82.

I I. Holton, Einstein, History, and Other Passions, I74-175.

I 2. Robert A. Millikan, "Albert Einstein on His Seventieth Birthday," Reviews of Modern Physics 2I (1949): 343-344.

13. Holton, Thematic Origins of Scientific Thought, ch. 8 and 477-480.

14. Cited in Robert S. Shankland, "Conversations with Albert Einstein," American Journal of Physics 3 I (1963):47-57.

15. Banesh Hoffmann, with Helen Dukas, Albert Einstein: Creator and Rebel (New York: Viking, 1972).

r6. Lewis S. Feuer, Einstein and the Generations of Science (New York: Basic Books, 1974).

17. New York Times, November 16, 19 19, 8.

r8. Cf. Einstein to Besso, May I3, I917, in Albert Einstein and Michele Besso, Correspondance, 1903-1955, tr. and Intro. Pierre Speziali (Paris: Hermann, I972), I 44.

19. For a classic exposition of the contrast between Kultur and Zivilisation, see N. Elias, Über den Prozess der Zivilisation, 2 vols. (Basel: Verlag Haus zum Falken, 1939), vol. $\mathrm{x}, \mathrm{I}-42$.

20. See, for example, Brockhaus Enzyklopädie, 1990.

21. Bruno Gebhard, Handbuch der Deutschen Geschichte, 8th ed. (Stuttgart: Union Verlag, 1962), vol. 3, 305.

22. Karl Mannheim, Ideology and Utopia: An Introduction to the Sociology of Knowledge (translation of Ideologie und Utopie, 1929; tr. Lewis Wirth and Edward Shils) (New York: Harcourt, Brace \& World, I970), I 56. By I 843 Karl Marx had noted (in his Kritik des Hegelschen Staatsrechts) that "Geld und Bildung" were the main criteria for social differentiation in the bürgerliche society; Marx, Karl Marx, Friedrich Engels, Werke, ed. Institut für Marxismus-Leninismus beim ZK der SED 
(Berlin: Dietz Verlag, 1957), vol. I, 203-333. For a useful summary of the Bildungsbürgertum, see F. Gregory, "Kant, Schelling, and the Administration of Science in the Romantic Era," Osiris (second series) 5 (1989): 17-35.

23. In the original sense of the educated Mandarinate that served the Chinese Empire and was chiefly concerned with administering or furthering the political and social needs of the state authorities. Fritz K. Ringer, The Decline of the German Mandarins: The German Academic Community, 1890-1933 (Cambridge, Mass.: Harvard University Press, 1969).

24. Christa Kirsten and Hans-Jürgen Treder, eds., Albert Einstein in Berlin, 19131933, 2 vols. (Berlin: Akademie-Verlag, 1979), vol. I, 207. This document collection contains reports to the German Foreign Office from German diplomats in The Hague, Oslo, Copenhagen, Paris, Buenos Aires, Tokyo, Madrid, Montevideo, Rio de Janeiro, Chicago, New York, and Vienna. See vol. I, $225-240$.

25. K. Mannheim, Ideologie und Utopie (Frankfurt: Verlag G. Schulte-Bulmke, I 969: first published in 1929), 22I-222.

26. For Albert Einstein's family tree, see Aron Tänzer, "Der Stammbaum Prof. Albert Einsteins," Jüdische Familien-Forschung: Mitteilungen der Gesellschaft für jüdische Familienforschung 7 (1931): 4 19-42r.

27. Erik Erikson, "Psychoanalytic Reflections on Einstein's Centenary," in Gerald Holton and Yehuda Elkana, eds., Albert Einstein: Historical and Cultural Perspectives (Princeton, N.J.: Princeton University Press, 1982; Dover Publications, Inc., 1997), I 5 I-173.

28. Maja Winteler-Einstein, “Albert Einstein-Beitrag für sein Lebensbild," The Collected Papers of Albert Einstein (Princeton, N.J.: Princeton University Press, 1987), vol. I, xlviii-lxvi.

29. Einstein, "Autobiographical Notes," 3-5.

30. Nevertheless, Helen Dukas insisted that Einstein's lifestyle in Zurich and Bern was "anything but 'bohemian," as noted in L. Pyenson, The Young Einstein: The Advent of Relativity (Bristol: Adam Hilger, 1985), 77, note 9. Pyenson would have characterized Einstein not as a rebel but as a stranger or marginal man (60-6I).

31. Seelig, Albert Einstein: Eine Dokumentarische Biographie, I25. The graduate student's name was Hans Tanner; Einstein supervised Tanner's dissertation while a professor at Zurich University.

32. Giuseppe Castagnetti and Hubert Goenner, "Directing a Kaiser-Wilhelm-Institut: Albert Einstein, Organizer of Science?” paper given at the Boston University Colloquium for Philosophy of Science, March 3, 1997.

33. Cited in Otto Nathan and Heinz Norden, eds., Einstein on Peace (New York: Schocken, 1968; reprint of 1960 edition), 157.

34. Letter to Hans Muehsam, March 30, 1954, Einstein Archive 38-434; cited in The Quotable Einstein, ed. Alice Calaprice (Princeton, N.J.: Princeton University Press, 1996), I 58. See also Einstein's declaration of his religiosity in Harry Graf Kessler, Tagebücher 1918-1937, ed. Wolfgang Pfeiffer-Belli (Frankfurt: Insel-Verlag, 1961), $521-522$, and in Hubert Goenner and Giuseppe Castagnetti, "Albert Einstein as Pacifist and Democrat during World War I," Science in Context 9 (1996): 348349. See also Albert Einstein, Ideas and Opinions (New York: Dell, 1954).

35. Ministerium der geistlichen, Unterrichts- und Medizinalangelegenheiten, 
"Lehrpläne und Lehraufgaben für die höheren Schulen, nebst Erläuterungen und Ausführungsbestimmungen" (Berlin: Wilhelm Hertz, 1892), 20.

36. Reiser, Albert Einstein: A Biographical Portrait, 26. Toward the end of his life, when Einstein's sister Maja visited him in Princeton (as Einstein wrote to Besso), both would spend their time together reading "Herodotus, Aristotle, Russell's History of Philosophy, and many other interesting books." Einstein and Besso, Correspondance; see also Albrecht Fölsing, Albert Einstein: Eine Biographie (Frankfurt: Suhrkamp, 1993), 819. One might add here that Heine was often excluded from the "official" cultural canon, especially outside Jewish circles, because of his religious background and his affiliation with French and revolutionary ideas.

37. See the introduction by Maurice Solovine to Albert Einstein, Letters to Solovine (New York: Philosophical Library, 1987), 8-9. Auguste Comte is notably absent from Einstein's reading list and exchanges. Comte remained relatively unknown in the German-speaking parts of Europe at the turn of the century.

38. Max Talmey, The Relativity Theory Simplified, and the Formative Period of Its Inventor (New York: Falcon Press, 1932), 164.

39. Seelig, Albert Einstein: Eine Dokumentarische Biographie, 17. The course was Professor Stadler's lecture course on "Die Philosophie I. Kants"; see Collected Papers, vol. $x, 364$.

40. Albert Einstein, "Elsbachs Buch: Kant und Einstein," Deutsche Literatur-zeitung I (n.f.) (1924), I685-1692.

4I. Immanuel Kant, Critique of Pure Reason, tr. Norman Kemp Smith (London: Macmillan, I929), I I 3 .

42. Albert Einstein, "Remarks Concerning the Essays Brought Together in This Cooperative Volume," in Albert Einstein: Philosopher-Scientist, 674.

43. This database for all books remaining after his death was compiled by NHK (Japan Broadcasting Corporation) and is scheduled to be published. A reading list of additional books may be found in Abraham Pais, 'Subtle Is the Lord . . $\therefore$ The Science and the Life of Albert Einstein (Oxford: Oxford University Press, 1982).

44. Isaiah Berlin, The Crooked Timber of Humanity, ed. Henry Hardy (New York: Vintage Books, x992), 213-216.

45. As Fritz Stern shrewdly observed in a passage mentioning both Goethe and Einstein: "A genius could also be seen as a public nuisance." Stern, Dreams and Delusions: The Drama of German History (New York: Alfred A. Knopf, 1987). See also the first chapter of that volume, entitled "Einstein's Germany." On the uses and abuses of Goethe by German ideologues, as well as on how Einstein's view of himself as a Jew differed from the view held by others, for example, Fritz Haber, see Stern, The Politics of Cultural Despair: A Study in the Rise of the Germanic Ideology (Berkeley: University of California Press, 196I).

46. Seelig, Albert Einstein: Eine Dokumentarische Biographie, 88-89.

47. It is also hinted at in a letter to Max Born, cited in Born, "Physics and Relativity," Helvetica Physica Acta, Supplementum IV (1956), 249.

48. Collected Papers, vol. 2, x 50.

49. Isaac Newton, Mathematical Principles of Natural Philosophy (translation of Philosophiae naturalis principia mathematica), 2 vols., original translation by Andrew 
Motte (1729), revised translation by Florian Cajori (Berkeley, Calif.: University of California Press, 1962), vol. 2, 398.

5o. The theme of unity and unification also played an important role in biology, as Vassiliki Smocovitis has documented in Unifying Biology: The Evolutionary Synthesis and Evolutionary Biology (Princeton, N.J.: Princeton University Press, 1996). William Morton Wheeler commented (as cited in Smocovitis, 109) that it might take "a few super-Einsteins" to unify biology, using Einstein as the icon of the theme of unification.

51. Pais, "Subtle Is the Lord ..., ," 9.

52. Pauline Mazumdar, Species and Specificity: An Interpretation of the History of Immunology (Cambridge: Cambridge University Press, 1995).

53. Gerald Holton, Science and Anti-Science (Cambridge, Mass.: Harvard University Press, 1993), I 2-I 5 .

54. Jürgen Renn and Robert Schulmann, "Introduction," in Albert Einstein-Mileva Maric: The Love Letters, ed. Renn and Schulmann (Princeton, N.J.: Princeton University Press, 1992), xii-xiii.

55. See Matthew Arnold, Culture and Anarchy, ed. Samuel Lipman (New Haven, Conn.: Yale University Press, 1994; first published in 1869 ).

56. Einstein kept sculptured busts of both Goethe and Schiller in his Berlin home. F. Herneck, Einstein privat: Herta W. erinnert sich an die Jahre 1927 bis 1933 (Berlin: Buchverlag Der Morgen, 1978), 47-48.

57. In the latter part of the nineteenth and in the early twentieth century, it was quite common to assemble "best book" lists of the outstanding works of literature. In I9I I, Heinrich Falkenberg compiled such a bibliography, "Listen der besten Bücher," in the Zeitschrift für Bücherfreunde; it comprised forty-six entries. The earliest such bibliography was Johann Neukirch's Dichterkanon of 1853; in Neukirch's compilation, as well as in the subsequent ones, Goethe played a dominant role. Around 1906, the Viennese bookseller Hugo Heller polled a number of intellectuals about their choice of the "ten best books." A selection of the responses was printed in the Jabrbuch deutscher Bibliophilen und Literaturfreunde, ed. H. Feigl (Zurich: Amalthea-Verlag, 1931), 108-127. As one might expect, Goethe figured prominently in these replies, both explicitly and implicitly.

58. Collected Papers, vol. I, 26-27.

59. George Henry Lewes, The Life of Goethe, 3rd ed. (London: Smith, Elder and Co., I 875$)$.

6o. Henry C. Hatfield, Goethe: A Critical Introduction (New York: New Directions, 1963), 28.

6r. And of course not only in German-speaking countries; to cite a single example, Ralph Waldo Emerson taught himself German specifically in order to read Goethe's works. See Robert D. Richardson, Emerson: The Mind on Fire (Berkeley, Calif.: University of California Press, 1995).

62. Johann Wolfgang von Goethe, Goethes Werke (Hamburger Ausgabe), 4th ed. (Hamburg: Christian Wegner Verlag, 1962), vol. r3, 7-ro.

63. Hatfield, Goethe: A Critical Introduction, 114.

64. Isaiah Berlin, Concepts and Categories (New York: Viking Press, 1979), passim.

65. Cited in Lewes, The Life of Goethe, 558. 
66. On the other hand, there can be no doubt that many of the Bildungsbürger and many of those aspiring to their ranks rampantly quoted from this and other classics merely to demonstrate their membership in the educated elite. Such people were greatly helped by Georg Büchmann's Geflügelte Worte: Der Zitatenschatz des deutschen Volkes, 27th ed. (Berlin: Haude \& Spenersche Buchhandlung, 1926), a bestselling compilation of classic quotations and lengthier excerpts that was first published in 1864 , and went through twenty-seven editions by 1926 . See Wolfgang Frühwald, "Büchmann und die Folgen: Zur sozialen Funktion des Bildungszitates in der deutschen Literatur," in Bildungsbürgertum im 19. Jahrhundert, part II: Bildungsgüter und Bildungswissen, ed. Reinhart Koselleck (Stuttgart: Klett-Cotta, 1990), 197-219.

67. Walter Moore, Schrödinger: Life and Thought (Cambridge: Cambridge University Press, 1989), 47.

68. Arnold Sommerfeld, Electrodynamics (volume three of his Lectures on Theoretical Physics, tr. Edward Ramberg) (New York: Academic Press, I952), 3 I I .

69. In a September 1900 letter to Marić. Collected Papers, vol. I, 260.

70. In Boltzmann's epigraphs, his rendering of Goethe's lines was, for Part I of his treatise: "So soll ich denn mit saurem Schweiss / Euch lehren, was ich selbst nicht weiss." For Part II, Boltzmann wrote: "War es ein Gott, der diese Zeichen schrieb, / Die mit geheimnissvoll verborg'nem Trieb / Die Kräfte der Natur um mich enthüllen / Und mir das Herz mit stiller Freude füllen.”

71. There is no authoritative picture of how Goethe imagined that heavenly Sign of the Macrocosmos, since no stage directions for it appear in the text of Faust. But we know at least the image that seems to have satisfied Goethe himself: in the $\mathbf{1 7 9 0}$ edition of volume 7 of his writings (which included Faust), he commissioned as a frontispiece a version of an etching by Rembrandt that historically was known as representing "Dr. Faust," named after the original sixteenth-century legendary figure (as shown in Figure 3).

72. Max Planck, "Die Einheit des physikalischen Weltbildes," in his Vorträge und Erinnerungen (Darmstadt: Wissenschaftliche Buchgesellschaft, 1970), 28-5 I.

73. David Cassidy, Einstein and Our World (Atlantic Highlands, N.J.: Humanities Press, 1995), I4.

74. Anne Harrington, Reenchanted Science: Holism in German Culture from Wilhelm II to Hitler (Princeton, N.J.: Princeton University Press, 1996), 5, ro.

75. See, for example, Peter Galison and David J. Stump, eds., The Disunity of Science: Boundaries, Contexts, and Power (Stanford, Calif.: Stanford University Press, I996), and Ian Hacking, "Disunified Sciences," in Richard Q. Elvee, ed., The End of Science? Attack and Defense (Nobel Conference XXV; St. Peter, Minn.: Gustavus Adolphus College, 1992), 33-52.

76. Henry Adams, The Education of Henry Adams: An Autobiography (Boston: Houghton Mifflin, 19r8). 